NIST Technical Note 2091

\title{
Tool for Evaluation of Vaporized Hydrogen Peroxide Disinfection of N95 Masks in Small Rooms
}

Dustin Poppendieck

This publication is available free of charge from:

https://doi.org/10.6028/NIST.TN.2091

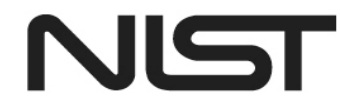

National Institute of Standards and Technology U.S. Department of Commerce 


\title{
Tool for Evaluation of Vaporized Hydrogen Peroxide Disinfection of N95 Masks in Small Rooms
}

\author{
Dustin Poppendieck \\ Indoor Air Quality and Ventilation Group \\ Energy and Environment Division \\ Engineering Laboratory
}

This publication is available free of charge from:

https://doi.org/10.6028/NIST.TN.2091

April 2020

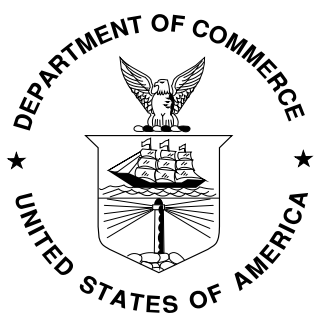

U.S. Department of Commerce Wilbur L. Ross, Jr., Secretary

National Institute of Standards and Technology Walter Copan, NIST Director and Undersecretary of Commerce for Standards and Technology 
Certain commercial entities, equipment, or materials may be identified in this document in order to describe an experimental procedure or concept adequately. Such identification is not intended to imply recommendation or endorsement by the National Institute of Standards and Technology, nor is it intended to imply that the entities, materials, or equipment are necessarily the best available for the purpose.

National Institute of Standards and Technology Technical Note 2091

Natl. Inst. Stand. Technol. Tech. Note 2091, 15 pages (April 2020)

CODEN: NTNOEF

This publication is available free of charge from: https://doi.org/10.6028/NIST.TN.2091 


\section{Abstract}

The SARS-CoV-2 virus has put a strain on the supply and distribution of N95 masks, with some hospitals electing to reuse masks after disinfection. Currently, vaporized hydrogen peroxide (VHP) mask disinfection systems are being deployed at multiple locations throughout the United States, for example in shipping containers and in small rooms. Such enclosures will be of a different size, have different surface materials and have varying air change rates; all these parameters will impact the VHP dose that the masks receive. This paper describes a spreadsheet tool to estimate the VHP concentration in air of such a room. The tool employs a single-zone mass balance analysis that accounts for room size, VHP losses to surfaces and air change rate. This tool is intended to support VHP disinfection efforts by providing estimates of VHP concentrations in the room being employed, but it does not describe or provide guidance on VHP disinfection applications. 


\section{Introduction}

The SARS-CoV-2 virus has put a strain on the supply and distribution of personal protection equipment, including N95 masks (Chaudhuri 2020, Nierenberg 2020). One approach to help alleviate this shortage is to disinfect and reuse masks. The disinfection process must be effective against the target organism, not damage the mask or impact the fit, and be safe for the wearer after disinfection (3M 2020). A wide range of physical or chemical processes have been proposed for disinfecting masks, including ultraviolet irradiation, hydrogen peroxide (liquid, vapor and plasma), microwaves, moist heat, ionization radiation and ethylene oxide (3M 2020, Centers for Disease Control and Prevention 2020).

Vaporized hydrogen peroxide (VHP) has been used in hospitals to disinfect medical equipment and rooms (Rutala et al. 2008, Otter et al. 2009, Canadian Agency for Drugs and Technologies in Health 2014, Rutala and Weber 2015). In addition, VHP has been recently demonstrated to eliminate aerosolized bacteriophages used as proxies for SARS-CoV-2 (e.g., T1, T7, and Pseudomonas phage phi-6) in masks (Kenney et al. 2020).

As of April 2, 2020, Battelle Memorial Institute is deploying VHP disinfectant systems (Figure 1, approved by FDA on March 29, 2020 (Hinton 2020)) in shipping containers across the United States to treat up to 80000 N95 masks per day (Hale 2020, Ostriker 2020). In addition to shipping container systems, some hospitals are setting up disinfection systems in small rooms (Medicine 2020). As SARS-CoV-2 continues to spread, more small rooms within hospitals or other locations may increasingly be used for disinfecting masks. Such rooms will be of a different size, have different surface materials and have varying air change rates; all these parameters will impact the effective VHP dose that the masks receive. Materials such as carpet have been shown to reduce indoor VHP concentrations by up to an order of magnitude (Corsi et al. 2005). Failure to account for surface losses in these rooms may inhibit effective N95 mask disinfection.

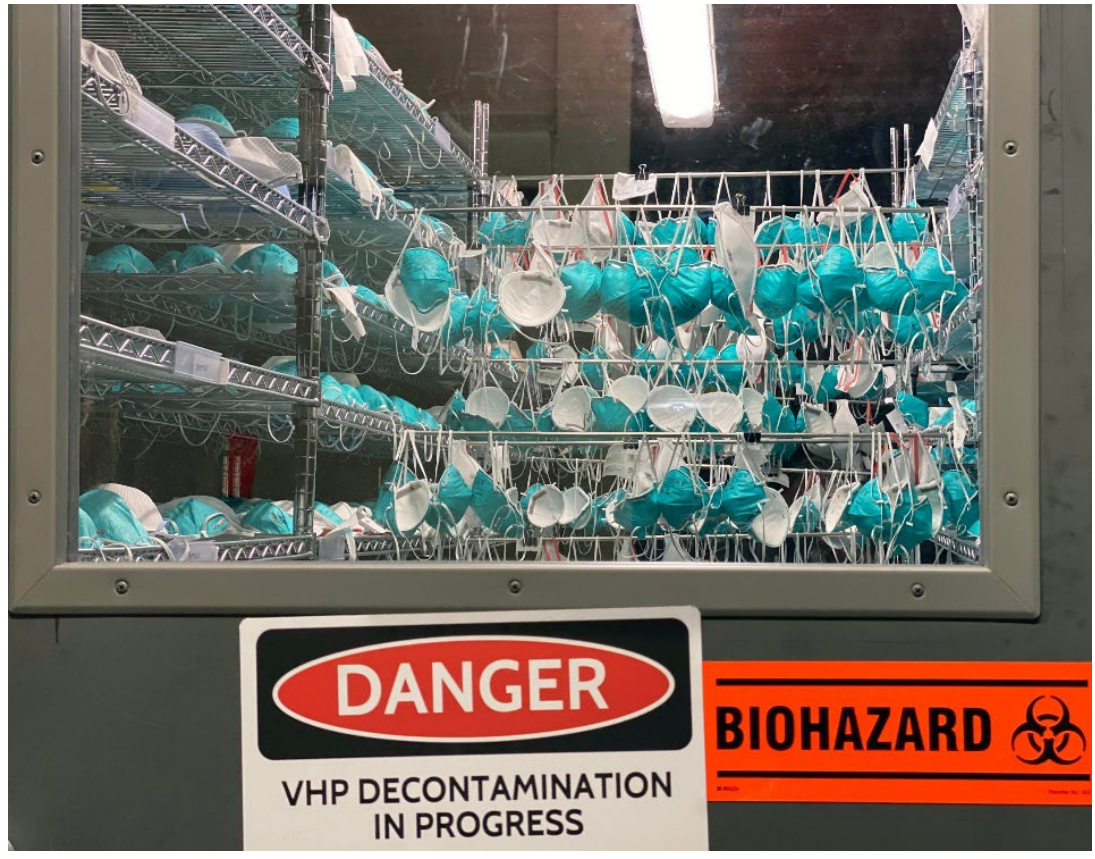

Figure 1: Battelle Memorial Institute VHP masks decontamination system. (Photo used with permission of John Clay). 
Room VHP concentrations have been reported to be in the range of 0.14 to $8 \mathrm{~g} \mathrm{~m}^{-3}$ (Battelle 2016, Centers for Disease Control and Prevention 2020). Note that these room concentrations used to disinfect masks using VHP may exceed NIOSH relative exposure limits $\left(0.0014 \mathrm{~g} \mathrm{~m}^{-3}\right.$ ) (Akers and Agalloco 2013, NIOSH 2020). Given the strong dependence of room or enclosure VHP concentrations on room size, surface materials and air change rates, those applying this approach need to estimate these concentrations when pursuing VHP disinfection of masks.

This paper describes a spreadsheet tool to estimate the VHP concentration in air of a room being used to disinfect masks that employs a single-zone mass balance analysis. This tool is intended to support VHP disinfection efforts by providing estimates of VHP concentrations in the chamber being employed, but it does not describe or provide guidance on VHP disinfection applications. Nor does it address safety considerations in using VHP for disinfection of masks (Akers and Agalloco 2013), including migration of vaporized hydrogen peroxide into adjacent rooms. Other important considerations include effective VHP dose, disinfection times, and air mixing in the room to ensure all masks are subject to similar VHP concentrations. These issues need to be addressed in consultation with facility management staff and with safety and occupational health personnel prior to using VHP to disinfect masks.

\section{Method}

This paper describes a spreadsheet tool that allows a user to estimate the VHP concentration in air of a room being used to disinfect masks. The tool accounts for room size, surface losses and air change rate using a mass balance approach. It can also be used to estimate the mass of disinfectant deposited on the masks. The tool employs a single zone analysis in which the VHP concentration is characterized by a single value throughout the room. The mass balance equations on which the tool is based are provided in the appendix. The tool can be downloaded from - https://www.nist.gov/servicesresources/software/tool-evaluation-vaporized-hydrogen-peroxide-disinfection-n95-masks-small.

Recent efforts to disinfect masks with VHP have employed a four-phase process: Conditioning, Gassing, Dwell, and Aeration (Battelle 2016, Kenney et al. 2020). The first phase, Conditioning, is the period during which the chamber is brought to the desired temperature and relative humidity and does not involve VHP injection, so it is not covered by this tool. During both the Gassing and Dwell phases VHP is injected into the room, with the former involving increased VHP flow to achieve the target concentration more rapidly. Gassing phase emissions sources and flow rates may be greater than those during Dwell phases. The Aeration phase is used to vent the chamber after the disinfection process has ended.

The tool allows the user to enter different durations, emission source strength, and flow rate for the Gassing, Dwell and Aeration phases. To use this tool, input data are entered into the green cells shown in Figure 2.

For the (1) Gassing and (2) Dwell phases:

- Enter the phase Duration (h).

- Enter the Mechanical flow into the room $\left(\mathrm{m}^{3} \mathrm{~h}^{-1}\right)$. This flow should not include any recirculating flow in closed-loop systems. The calculated Air change rate $\left(h^{-1}\right)$ for each phase is the sum of the Infiltration rate $\left(\mathrm{h}^{-1}\right)$ and Mechanical ventilation multiplied by the Room volume. If the Mechanical Flow is unknown, adjust the Mechanical Flow and Infiltration rate values until a 
realistic Air change rate value for the phase is displayed. See the Infiltration Rate discussion below for more details.

\section{Inputs}

\begin{tabular}{|c|c|}
\hline \multicolumn{2}{|l|}{ 1) Gassing Phase } \\
\hline Duration, h & 0.33 \\
\hline Mechanical Flow, $\mathrm{m}^{3} \mathrm{~h}^{-1}$ & 1.00 \\
\hline Total Air change rate, $\lambda, \mathrm{h}^{-1}$ & 0.17 \\
\hline \multicolumn{2}{|l|}{ a) In Room Source } \\
\hline Emission source in room $\mathrm{E}, \mathrm{g} \mathrm{h}^{-1}$ & 120 \\
\hline \multicolumn{2}{|l|}{ b) Injection Source } \\
\hline Concentration in injected air, $\mathrm{C}_{\mathrm{inj}}, \mathrm{g} \mathrm{m}^{-3}$ & 0 \\
\hline Flow rate of injected air, $Q_{i n j}, m^{3} h^{-1}$ & 0 \\
\hline
\end{tabular}

\begin{tabular}{|c|c|}
\hline \multicolumn{2}{|l|}{ 2) Dwell Phase } \\
\hline Duration, $\mathrm{h}$ & 2.50 \\
\hline Mechanical Flow, $\mathrm{m}^{3} \mathrm{~h}^{-1}$ & 1.00 \\
\hline Total Air change rate, $\lambda, \mathrm{h}^{-1}$ & 0.17 \\
\hline \multicolumn{2}{|l|}{ a) In Room Source } \\
\hline Emission source in room $\mathrm{E}, \mathrm{g} \mathrm{h}^{-1}$ & 80 \\
\hline \multicolumn{2}{|l|}{ b) Injection Source } \\
\hline Concentration in injected air, $\mathrm{C}_{\mathrm{inj}}, \mathrm{g} \mathrm{m}^{-3}$ & 0 \\
\hline Flow rate of injected air, $\mathrm{Q}_{\mathrm{inj}}, \mathrm{m}^{3} \mathrm{~h}^{-1}$ & 0 \\
\hline
\end{tabular}

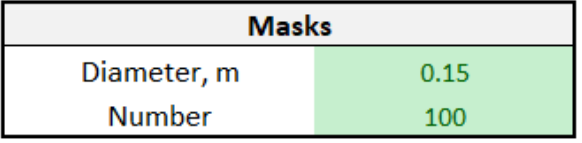

\begin{tabular}{|cc|}
\hline \multicolumn{1}{|c|}{ Room } \\
\hline Length, $\mathrm{m}$ \\
Width, $\mathrm{m}$ \\
Height, $\mathrm{m}$ & 3 \\
Initial Concentration, \\
C $_{\text {initial, } \mathrm{g} \mathrm{m}^{-3}}$ \\
Infiltration rate, $\mathrm{\lambda}, \mathrm{h}^{-1}$ \\
\hline
\end{tabular}

3) Aeration Phase

Duration, h

0.50

Mechanical Flow, $\mathrm{m}^{3} \mathrm{~h}^{-1}$

Total Air change rate, $\lambda, \mathrm{h}^{-1}$

200.0

13.43

\begin{tabular}{|c|c|c|c|c|}
\hline Surfaces & $\begin{array}{c}\text { Surface adsorption } \\
\text { area, } \mathrm{A}, \mathrm{m}^{2}\end{array}$ & Surface material & $\begin{array}{l}\text { Deposition Velocity, } \\
\qquad \mathrm{V}_{\mathrm{d}}, \mathrm{cm} \mathrm{h}^{-1}\end{array}$ & $V d^{*} A / V, h^{-1}$ \\
\hline Walls & 25 & Concrete w/Sealer & 600 & 10.0 \\
\hline Ceiling & 6 & Concrete & 800 & 3.2 \\
\hline Floor & 6 & VCT & 75 & 0.3 \\
\hline Masks & 3.5 & Paper/HVAC Duct & 600 & 1.4 \\
\hline Other Surfaces with Large Areas & 0.0 & - & 0 & 0.0 \\
\hline
\end{tabular}

Figure 2: The input screen of the disinfection tool.

VHP can either be released directly inside the room using a VHP generator or injected into the room using a generator located outside the room. Emission rates for the release process not being used should be input as zero. Set the VHP source strength for Gassing and Dwell phases as follows:

- Emission source in the room. If the VHP source is in the room, enter the emission rate $\left(\mathrm{g} \mathrm{h}^{-1}\right)$. Use this option if the generation system is externally located but operates on a "closed loop 
cycle." Previous mask disinfection research used in-room VHP sources emitting at a rate of $120 \mathrm{~g} \mathrm{~h}^{-1}$ to $960 \mathrm{~g} \mathrm{~h}^{-1}$ (Battelle 2016, Centers for Disease Control and Prevention 2020, Kenney et al. 2020).

$\circ$ Enter the Emission source in room $\left(\mathrm{g} \mathrm{h}^{-1}\right)$

- Enter zero for the Concentration in injected air $\left(\mathrm{g} \mathrm{m}^{-3}\right)$

$\circ \quad$ Enter zero for the Flow rate of injected air $\left(\mathrm{g} \mathrm{m}^{-3}\right)$

- Generated outside the room. If the VHP source is external to the room, enter the injection rate to the room $\left(\mathrm{g} \mathrm{m}^{-3}\right)$. This option is provided for completeness. No known mask disinfection systems have been implemented in this manner to the knowledge of the author.

- Enter zero for the Emission source in the room $\left(\mathrm{g} \mathrm{h}^{-1}\right)$

$\circ$ Enter the Concentration in injected air $\left(\mathrm{g} \mathrm{m}^{-3}\right)$

$\circ$ Enter the Flow rate of injected air $\left(\mathrm{m}^{3} \mathrm{~h}^{-1}\right)$.

For the (3) Aeration phase:

- Enter the phase Duration (h).

- Enter the Mechanical flow into the room $\left(\mathrm{m}^{3} \mathrm{~h}^{-1}\right)$. See the Infiltration Rate discussion below for more details about the Air change rate.

Mask and room properties are entered on the right side of the input screen.

- Masks. Diameter of mask (m), assuming it is circular. This value is used to calculate the total surface area of the mask including both sides. Enter the Number of masks being disinfected inside the room.

- Dimensions. Length, width and height of the room $(\mathrm{m})$

- Initial Concentration in room. Initial VHP concentration in the room $\left(\mathrm{g} \mathrm{m}^{-3}\right)$. In most cases this value will be zero.

- Estimate the Infiltration rate for the room $\left(\mathrm{h}^{-1}\right)$. The infiltration rate is the rate at which air enters the room when the disinfection system is not running and the room is isolated from the building ventilating systems (i.e., supply, return and exhaust vents are sealed). Rarely is the infiltration rate zero. Very airtight rooms may have infiltration rates as low as $0.1 \mathrm{~h}^{-1}$. More typical rooms may have infiltration rates from about $0.3 \mathrm{~h}^{-1}$ to $0.5 \mathrm{~h}^{-1}$ or even higher (Persily et al. 2009). These values are estimates for use in these calculations; the user should consider the specific room in their application in consultation with engineering, facility and safety staff in estimating or measuring this parameter. In general, a higher estimated infiltration rate will be more conservative as it will lead to lower calculated VHP concentrations. It will also lead to shorter estimated times before the room concentration returns to background levels during the aeration phase, which need to be considered in planning disinfection efforts.

- Enter the Surface materials and the Deposition velocities $\left(\mathrm{cm} \mathrm{h}^{-1}\right)$ for each material.

Work by Corsi et al. (2005) determined hydrogen peroxide deposition velocities using a Bioquell Clarus-C generator operated in closed-loop mode using $50 \% \mathrm{H}_{2} \mathrm{O}_{2}$ producing a VHP chamber concentration of $1 \mathrm{~g} \mathrm{~m}^{-3}$. Test were done on 23 different building materials using $50 \mathrm{~L}$ chambers at room temperature with an air change rate of $2.4 \mathrm{~h}^{-1}$. These data are presented in Figure 3. 
To account for deposition processes, the user should determine the surface materials that best represent the walls, ceiling, floor and any other materials of substantial surface area in the room. Once the appropriate materials are identified, determine the deposition velocity from Figure 3. In Figure 3, VCT is vinyl composite tile, MDF is medium density fiberboard and GWB is gypsum wall board. Once the appropriate materials are selected, determine the approximate deposition velocity from Figure 3 . The deposition velocities characterize how fast the VHP is removed by the various surfaces.

In ideal cases, there is nothing in the disinfection room for VHP to deposit to other than the walls, ceiling, floor, masks and mask racks. If there is a large surface area of another material in the room, that area can be accounted for in the last surface input. The total exposed area of these surfaces should be entered $\left(\mathrm{m}^{2}\right)$ and a deposition velocity best representing the surfaces should be selected from Figure 3 for the large surface.

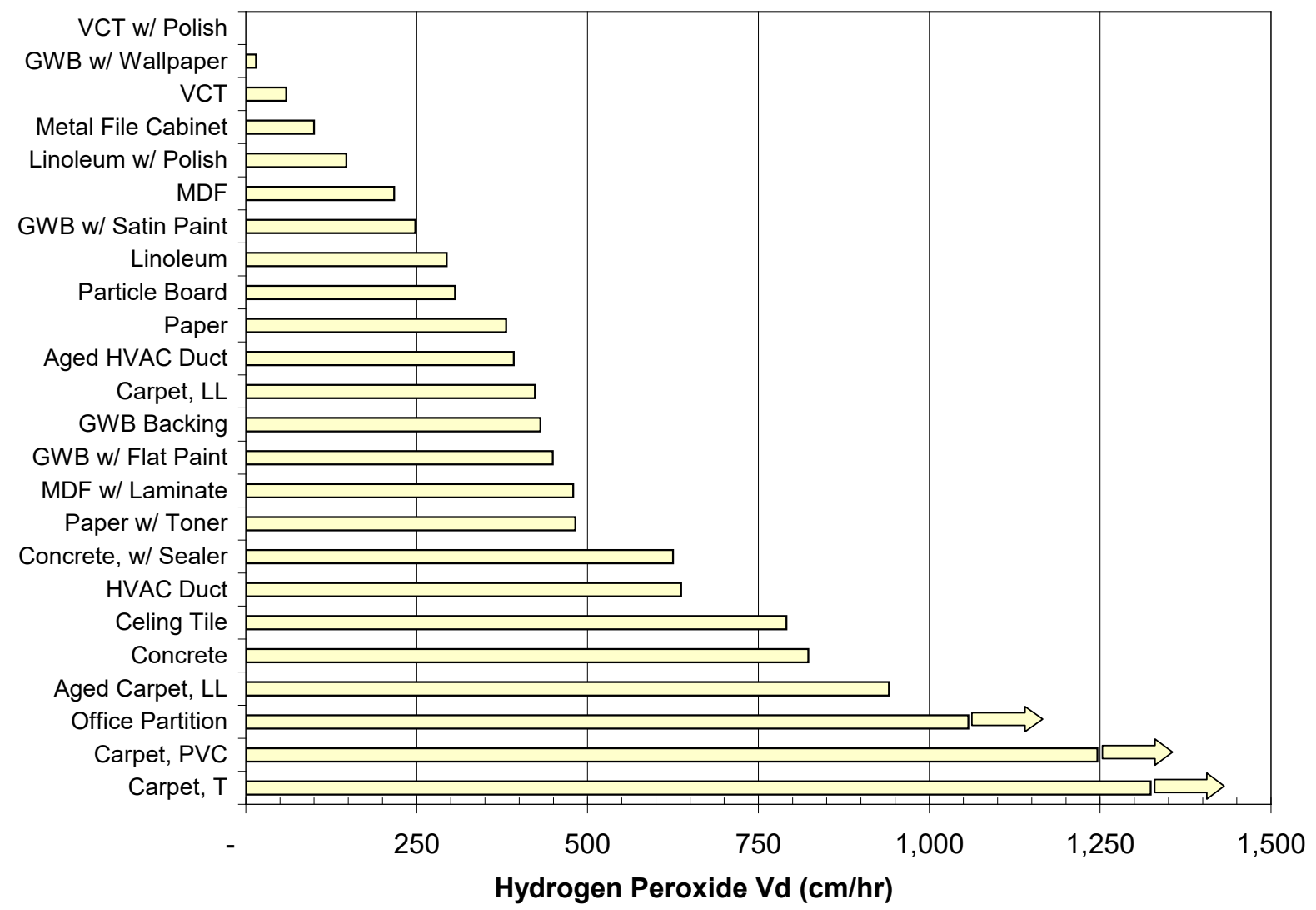

Figure 3: Steady-state hydrogen peroxide deposition velocities over all experiments (arrows indicate values greater than the bar length shown). Reproduced from Corsi et al. (2008). Values with arrows indicate minimum deposition velocity values due to VHP concentrations below detection limits for these materials.

The model will automatically update the results as soon as any cells are entered. The worksheet has two tabs (shipping container and general room). The calculations in each tab are identical and either tab can be modified. 


\section{Results}

The model has both tabular and graphical output. The table in Figure 4 summarizes the results. The first line shows the maximum predicted room airborne VHP concentration when surface losses are accounted for, and the second line shows the maximum concentration without surface losses. The third line shows how much lower the peak concentration will be when losses due to surfaces are accounted for compared to the case without losses. The fourth line shows the VHP dose that the masks are estimated to experience (the integration of concentration multiplied over time). The fifth line predicts what percent of the injected mass will be deposited onto the masks. The last line predicts what percent of the injected mass will be deposited onto the room surfaces.

\section{Results}

\begin{tabular}{|l|c|}
\hline Maximum predicted room concentration with surface losses, $\mathrm{g} \mathrm{m}^{-3}$ & 1.11 \\
\hline Maximum predicted room concentration with no surface losses, $\mathrm{g} \mathrm{m}^{-3}$ & 4.15 \\
\hline $\begin{array}{l}\text { Ratio of maximum predicted room concentration with surface deposition and predicted } \\
\text { room concentration with no surface deposition }\end{array}$ & $27 \%$ \\
\hline Cumulative predicted disinfectant dose with surface losses $\left(\mathrm{g} \mathrm{m}^{-3} \mathrm{~h}\right)$ & 1.47 \\
\hline Percent of disinfectant mass injected/emitted into room deposited onto masks & $23 \%$ \\
\hline Percent of disinfectant mass injected/emitted into room deposited onto room surfaces & $50 \%$ \\
\hline
\end{tabular}

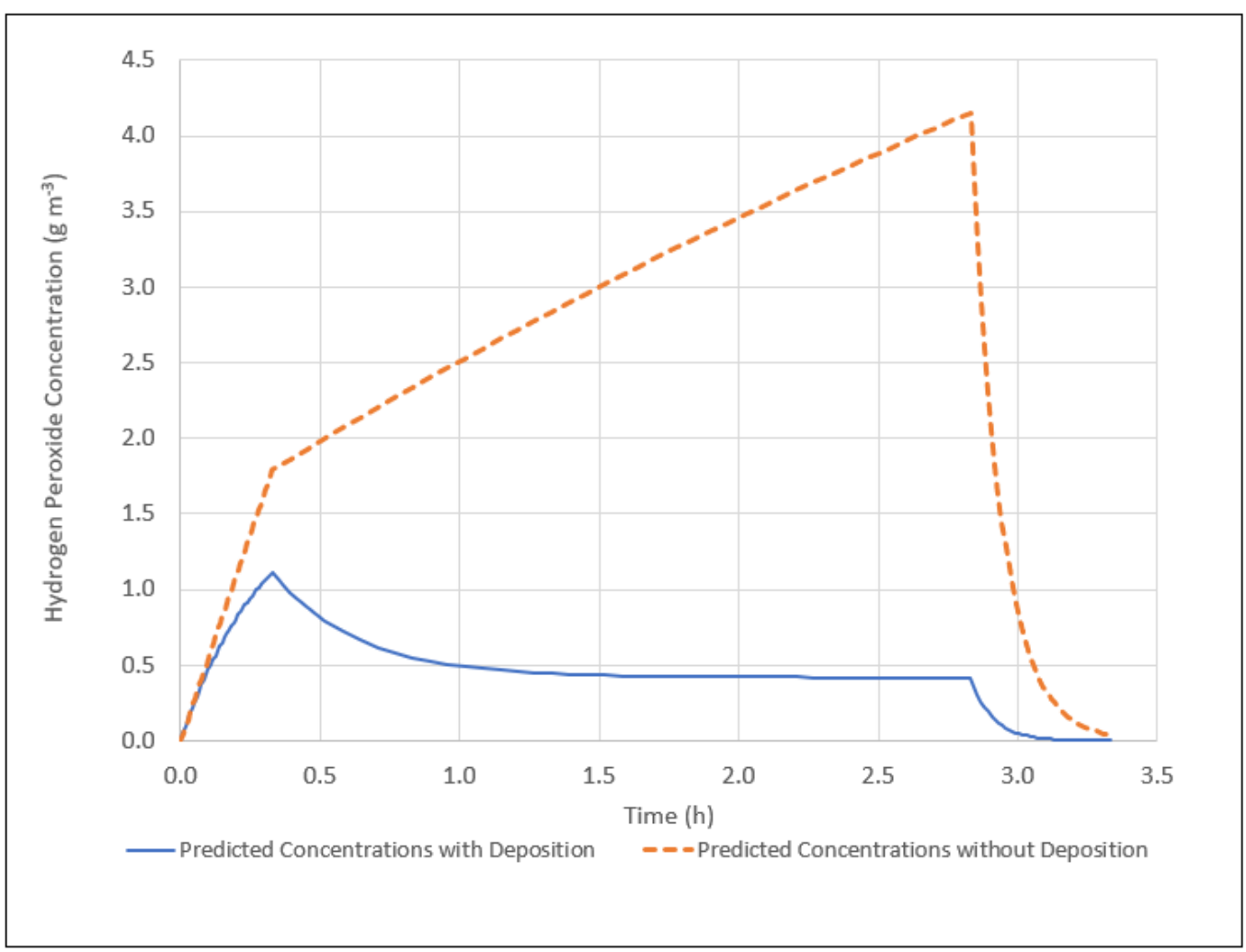

Figure 4: Results of model. Graph shows room airborne VHP concentration predictions with and without surfaces losses accounted for. 
Figure 4 shows the room airborne VHP concentration predictions for conditions where the losses to room surfaces are accounted for (solid blue) and are not accounted for (dashed orange). The difference in these lines for this case demonstrates the role that room surfaces have in impacting the disinfectant dose to the masks.

The second table in the results section (not shown in Figure 4) describes parameter values. The calculated Total airflow values $\left(\mathrm{m}^{3} \mathrm{~h}^{-1}\right)$ for each phase includes the Mechanical Flow, the Flow rate for the injection system, and Infiltration air. The Total loss rate for each phase accounts for losses to surfaces and total airflow.

\section{Summary}

This tool can be used to estimate the concentration of hydrogen peroxide disinfectant in a mask disinfectant room utilizing Vaporized Hydrogen Peroxide (VHP) to help plan an effective VHP disinfection application by predicting the concentration of the disinfectant received by masks. The model predicts that rooms with lower surface-to-volume ratios, lower air change rates, fewer masks and surface materials with lower hydrogen peroxide deposition velocities (Figure 3 ) will result in higher steady state VHP concentrations.

This tool does not describe or provide guidance on VHP disinfection applications, including safety issues that should be addressed in consultation with facility management staff and with safety and occupational health personnel prior to using VHP to disinfect masks.

\section{Acknowledgement}

The author would like to acknowledge the contributions of Heidi Hubbard and Matthew Ward who collected the original deposition velocity data used in this tool. In addition, the author would like to thank Mengyan Gong and Richard Corsi for their efforts regarding model development and document review.

\section{License}

This tool was developed by employees of the National Institute of Standards and Technology (NIST), an agency of the Federal Government, and is being made available as a public service. Pursuant to title 17 United States Code section 105, works of NIST employees are not subject to copyright protection in the United States. This tool may be subject to foreign copyright. Permission in the United States and in foreign countries, to the extent that NIST may hold copyright, to use, copy, modify, create derivative works, and distribute this tool and its documentation without fee is hereby granted on a non-exclusive basis, provided that this notice and disclaimer of warranty appears in all copies.

THE TOOL IS PROVIDED 'AS IS' WITHOUT ANY WARRANTY OF ANY KIND, EITHER EXPRESS, IMPLIED, OR STATUTORY, INCLUDING, BUT NOT LIMITED TO, ANY WARRANTY THAT THE TOOL WILL CONFORM TO SPECIFICATIONS, ANY IMPLIED WARRANTIES OF MERCHANTABILITY, FITNESS FOR A PARTICULAR PURPOSE, AND FREEDOM FROM INFRINGEMENT, AND ANY WARRANTY THAT THE DOCUMENTATION WILL CONFORM TO THE TOOL, OR ANY WARRANTY THAT THE TOOL WILL BE ERROR-FREE. IN NO EVENT SHALL NIST BE LIABLE FOR ANY DAMAGES, INCLUDING, BUT NOT LIMITED TO, DIRECT, INDIRECT, SPECIAL OR CONSEQUENTIAL DAMAGES, ARISING OUT OF, RESULTING FROM, OR IN ANY WAY 
CONNECTED WITH THIS TOOL, WHETHER OR NOT BASED UPON WARRANTY, CONTRACT, TORT, OR OTHERWISE, WHETHER OR NOT INJURY WAS SUSTAINED BY PERSONS OR PROPERTY OR OTHERWISE, AND WHETHER OR NOT LOSS WAS SUSTAINED FROM, OR AROSE OUT OF THE RESULTS OF, OR USE OF, THE TOOL PROVIDED HEREUNDER. 


\section{Appendix}

Single-zone mass balance equation for a room accounting for ventilation, source and deposition:

$\frac{d C}{d t}=\frac{Q_{\text {inj }}}{V} \cdot C_{i n j}-\lambda \cdot C+\frac{E}{V}-V_{d 1} \cdot \frac{A_{1} \cdot C}{V}-V_{d 2} \cdot \frac{A_{2} \cdot C}{V}-V_{d 3} \cdot \frac{A_{3} \cdot C}{V}-V_{d 4} \cdot \frac{A_{4} \cdot C}{V}$

Where:

$\begin{array}{ll}C & \text { Chamber concentration, } \mathrm{g} \mathrm{m}^{-3} \\ t & \text { Time, } \mathrm{h} \\ \lambda & \text { air change rate, } \mathrm{h}^{-1} \\ C_{i n j} & \text { Injected Concentration, } \mathrm{g} \mathrm{m}^{-3} \\ Q_{i n j} & \text { Injected flow rate, } \mathrm{m}^{3} \mathrm{~h}^{-1} \\ E & \text { Emission rate, } \mathrm{g} \mathrm{h}^{-1} \\ V & \text { Room volume, } \mathrm{m}^{3} \\ V_{d, i} & \text { Deposition velocity for material } \mathrm{i}, \mathrm{m} \mathrm{h}^{-1}\end{array}$

$A_{i} \quad$ Area of material i, $\mathrm{m}^{2}$

The analytical solution for the concentration in the room air is:

$C=C_{0} \cdot \exp (-k \cdot t)+\frac{Q_{i n j} \cdot C_{i n j}+E}{k V}(1-\exp (-k \cdot t))$

Where

Co Initial room concentration (typically zero), $\mathrm{g} \mathrm{m}^{-3}$

$k \quad$ Total loss rate, $\mathrm{h}^{-1}$

$k=\lambda+\frac{Q i n j}{V}+V_{d 1} \cdot \frac{A_{1}}{V}+V_{d 2} \cdot \frac{A_{2}}{V}+V_{d 3} \cdot \frac{A_{3}}{V}+V_{d 4} \cdot \frac{A_{4}}{V}+V_{d 5} \cdot \frac{A_{5}}{V}$

The analytical solution was applied to each phase with the initial room concentration for each phase being determined by the last room concentration of the previous phase.

Assuming the disinfection dose can be calculated by multiplying the airborne concentration by time, the dose can be determined by:

$D=\int_{0}^{t} C d t=\left(\frac{C_{0}}{k} \cdot(1-\exp (-k \cdot t))+\frac{Q_{i n j} \cdot C_{i n j}+E}{k V}\left(t+\frac{1}{k}(1-\exp (-k \cdot t))\right.\right.$

Where:

$D \quad$ Dose, $\mathrm{g} \mathrm{m}^{-3} \mathrm{~h}^{-1}$

To compare to calculations without accounting for deposition the solution for the concentration in the room air is:

$C=C_{0} \cdot \exp (-\lambda \cdot t)+\left(\frac{Q_{i n j} \cdot C_{i n j}+E}{\lambda V}\right)(1-\exp (-\lambda \cdot t))$

In addition, the disinfectant mass deposited on each material can be determined by: 
$M_{i}=\int_{0}^{t} V_{d i} \cdot A_{i} \cdot C d t=V_{d i} \cdot A_{i}\left(\frac{C_{0}}{k} \cdot(1-\exp (-k \cdot t))+\frac{Q_{i n j} \cdot C_{i n j}+E}{k V}\left(t+\frac{1}{k}(1-\exp (-k \cdot t))\right.\right.$

Where:

$M_{i} \quad$ Disinfectant mass on material $\mathrm{i}, \mathrm{g}$

\section{References}

3M. (2020). "Technical Bulletin: Disinfection of Filtering Facepiece Respirators." from https://multimedia.3m.com/mws/media/18165760/disinfection-of-disposable-respiratorstechnical-bulletin.pdf.

Akers, J. E. and J. P. Agalloco (2013). "Overcoming Limitations of Vaporized Hydrogen Peroxide." Pharmaceutical Technology 37(9).

Battelle. (2016). "Final Report for the Bioquell Hydrogen Peroxide Vapor (HPV) Decontamination for Reuse of N95 Respirators." from https://www.fda.gov/media/136386/download.

Canadian Agency for Drugs and Technologies in Health (2014). Non-Manual Techniques for Room Disinfection in Healthcare Facilities: A Review of Clinical Effectiveness and Guidelines https://www.ncbi.nlm.nih.gov/books/NBK264205/

Centers for Disease Control and Prevention. (2020). "Decontamination and Reuse of Filtering Facepiece Respirators using Contingency and Crisis Capacity Strategies." Retrieved 4/2/2020, from https://www.cdc.gov/coronavirus/2019-ncov/hcp/ppe-strategy/decontamination-reuserespirators.html.

Chaudhuri, S. (2020). Coronavirus Prompts Hospitals to Find Ways to Reuse Masks Amid Shortages. A shortage of $\mathrm{N} 95$ masks has hospitals and research firms using chemicals and ultraviolet light to decontaminate and reuse the protective gea. The Wall Street Journal. https://www.wsj.com/articles/coronavirus-prompts-hospitals-to-find-ways-to-reuse-masksamid-shortages-11585647000

Corsi, R., H. Hubbard and D. Poppendieck (2008). Hydrogen peroxide vapor as a building disinfectant: Removal to indoor materials and formation of building disinfection by-products. Indoor Air 2008, Copenhagen, Denmark.

Corsi, R., H. Hubbard, M. Ward and D. Poppendieck (2005). Building Disinfection By-Products (BDBPs): Experimental Evaluation and Decision Tool; Volume 4: Hydrogen Peroxide Final Test Report, University of Texas at Austin: 146.

Hale, C. (2020). "Battelle deploys decontamination system for reusing N95 masks." Retrieved April 2, 2020, 2020, from https://www.battelle.org/newsroom/news-details/battelle-deploysdecontamination-system-for-reusing-n95-masks.

Hinton, D. (2020). FDA Approval Letter. Chief Scientist and Food and Drug Administration. https://www.battelle.org/docs/default-source/commercial-offerings/industrysolutions/battelle-eua.pdf?sfvrsn=646b94e 2 
Kenney, P., B. K. Chan, K. Kortright, M. Cintron, N. Havill, M. Russi, J. Epright, L. Lee, T. Balcezak and R. Martinello (2020). "Hydrogen Peroxide Vapor sterilization of N95 respirators for reuse." medRxiv: 2020.2003.2024.20041087.

Medicine, D. U. S. o. (2020). "Duke Starts Novel Decontamination of N95 Masks to Help Relieve Shortages." from https://medschool.duke.edu/about-us/news-and-communications/medschool-blog/duke-starts-novel-decontamination-n95-masks-help-relieve-shortages.

Nierenberg, A. (2020). Where Are All the Masks? In the United States, there is a shortage of medical equipment. What's going on? New York Times. https://www.nytimes.com/article/face-maskscoronavirus.html

NIOSH. (2020). "Hydrogen peroxide." from https://www.cdc.gov/niosh/idlh/772841.html.

Ostriker, R. (2020). Boston hospitals getting 'game changer' machine that sterilizes 80,000 protective masks a day. Boston Globe. https://www.bostonglobe.com/2020/04/02/metro/bostonhospitals-getting-game-changer-machine-that-sterilizes-80000-protective-masksday/?s campaign=breakingnews:newsletter

Otter, J., M. Puchowicz, D. Ryan, J. Salkeld, T. Cooper, N. Havill, K. Tuozzo and J. Boyce (2009). " Feasibility of Routinely Using Hydrogen Peroxide Vapor to Decontaminate Rooms in a Busy United States Hospital." Infection control and hospital epidemiology 30: 574-577.

Persily, A., H. Davis, S. J. Emmerich and W. S. Dols (2009). NISTIR 7546 Airtightness Evaluation of Shelterin-Place Spaces for Protection Against Airborne Chembio Releases. U. S. D. o. Commerce. https://tsapps.nist.gov/publication/get pdf.cfm?pub id=901117

Rutala, W. and D. Weber (2015). 301 - Disinfection, Sterilization, and Control of Hospital Waste. Mandell, Douglas, and Bennett's Principles and Practice of Infectious Diseases (Eighth Edition). J. E. Bennett, R. Dolin and M. J. Blaser. 2: 3294-3309.e3294.

Rutala, W. A., D. J. Weber, Healthcare and I. C. P. A. Committee. (2008). "Guideline for Disinfection and Sterilization in Healthcare Facilities, 2008; Update May 2019." from https://www.cdc.gov/infectioncontrol/pdf/guidelines/disinfection-guidelines-H.pdf. 